\title{
Mecistogaster amalia (Burmeister) Odonata: Pseudostigmatidae: First Record from Rio Grande do Sul State, Brazil
}

\begin{abstract}
Marina Schmidt Dalzochio ${ }^{\circledR}{ }^{\bowtie}$ Yji Urakami² \& Iberê Farina Machado ${ }^{1}$
1. University of Vale do Rio dos Sinos (UNISINOS), Laboratory of Ecologia e Conservação de Ecossistemas Aquáticos, e-mail: mahsdalzochio@gmail.com (Autor para correspondência ${ }^{\bowtie}$ ), iberemachado@gmail.com. 2. Biota Soluções Ambientais, e-mail: yugi.bio@gmail.com.

EntomoBrasilis 4 (2): 78-79 (2011)

Abstract. Mecistogaster is a New World genus of Pseudostigmatidae (Odonata) that is poorly studied due to its preference for flying in forest clearings and trails. In Brazil, only one endemic species, Mecistogaster amalia (Burmeister), is known. The distribution of $M$. amalia extends from Southest Brazil (Rio de Janeiro and São Paulo states) to Argentina. Herein, we report M. amalia for the first time in Rio Grande do Sul State, Southern Brazil. This record extends the species' range ca. $630 \mathrm{~km}$ from the previous report at Paranaense Forest in Misiones province.
\end{abstract}

Keywords: Distribution; Phytotelma; Zygoptera

\section{Mecistogaster amalia (Burmeister) Odonata: Pseudostigmatidae: Primeiro Registro para o Estado do Rio Grande do Sul, Brasil}

Resumo. Mecistogaster é um gênero da Família Pseudostigmatidae, restrito ao Novo Mundo e pobremente estudado devido sua preferencia por clareiras e trilhas dentro de matas. No Brasil, apenas uma espécie é conhecida, Mecistogaster amalia (Burmeister). A distribuição de M. amalia se estende do sudeste do Brasil (nos estados do Rio de Janeiro e São Paulo) até a Argentina. Aqui, reportamos pela primeira vez M. amalia para o estado do Rio Grande do Sul State, Sul do Brasil. O presente estudo amplia o registro de ocorrência da espécie em 630 km, a partir do registro anterior na Floresta Paranaense, na Província de Missiones, Argentina.

Palavras-Chave: Distribuição; Fitotelmata; Zygoptera

$\mathbf{T}$ he genus Mecistogaster Rambur is characterized by long and narrow wings, a nodus that is $1 / 4$ the length of the wing, only one row of cells between $\mathrm{Cu}_{2}$ and the wing margin, an M4 that is often not bifurcated before reaching the wing margin and a cerci much longer than the rudimentary paraproctus. This group is found throughout Brazil, although some species are geographically limited. However, they are rarely seen due to their preference for flying in forest clearings and trails. The genus comprises nine New World species (Bissy et al. 2010), seven of which can be found in Brazil: Mecistogaster amalia (Burmeister), Mecistogaster asticta Selys, Mecistogaster buckleyi McLachlan, Mecistogaster linearis (Fabricius), Mecistogaster lucretia (Drury), Mecistogaster ornate Ramburand Mecistogaster pronoti Sjöstedt (LENCIONI 2005). M. amalia is a South American species that is characterized by the anterior margin of the hind wing of the male being strongly pronounced, an anteriad at the pseudostigma and a particular circus pattern (Figure 1). They breed in phytotelmata, or tree holes. The distribution of $M$. amalia extends from southeastern Brazil (states of Rio de Janeiro and São Paulo) to Argentina (Lencioni 2005; VoN Ellenrieder \& PAUlson 2006; MuZón et al., 2010) (Figure 2). Originally described under genus Agrion, there are numerous synonyms: Mecistogaster filiformis Rambur; Mecistogaster leucostigma Rambur, 1842; Mecistogaster linearis Rambur (nec Fabricius, 1776), 1842; Agrion linearis (Blanchard (nec Fabricius 1776) 1840); Mecistogaster virgata Rambur, 1842 . We report $M$. amalia for the first time in Rio Grande do Sul State, southern Brazil. This record extends this species' range ca. $630 \mathrm{~km}$ from the previous report at Paranaense forest in Misiones province.
The specimens studied in the present paper were collected at Palanquinhos Canyon, between the cities of Caxias do Sul and São Francisco de Paula in Rio Grande do Sul State (Figure 2). One male was collected by a wildlife rescue team during the filling of a small hydropower plant at the Palanquinho Reservoir. The Specimens (Figure 1a) were identified using the keys in Lencioni (2005) and Heckman (2006). The specimens was collected from a tree trunk on the banks of the Lageado Grande River (-28 $\left.8^{\circ} 8^{\prime} \mathrm{S},-50^{\circ} 47^{\prime} \mathrm{W}\right), 10 / 05 / 2010$, one male (Figure 2). All specimens were deposited in the Entomology Collection of the Zoobotanic Foundation Museum of Natural Science, in Porto Alegre, Rio Grande do Sul, Brazil.

The specimens examined perfectly match the description of $M$. amalia and do not show significant morphological variation. The species is included in the IUCN Red List of Threatened Species as a data-deficient species. Despite its estimated distribution of about $225,000 \mathrm{~km}^{2}$, more data is needed to establish population trends and to evaluate threats to the species. This species' habitat is threatened by deforestation (VON ELLENRIEdER \& PAULSON 2006). The discovery of this species in southern Brazil suggests that although the Odonata fauna of southern Brazil is well known, there are still unexplored environments where there may be species not yet reported. More detailed taxonomic efforts should be made to describe the wildlife of these environments in order to facilitate future studies of distribution and species conservation. 

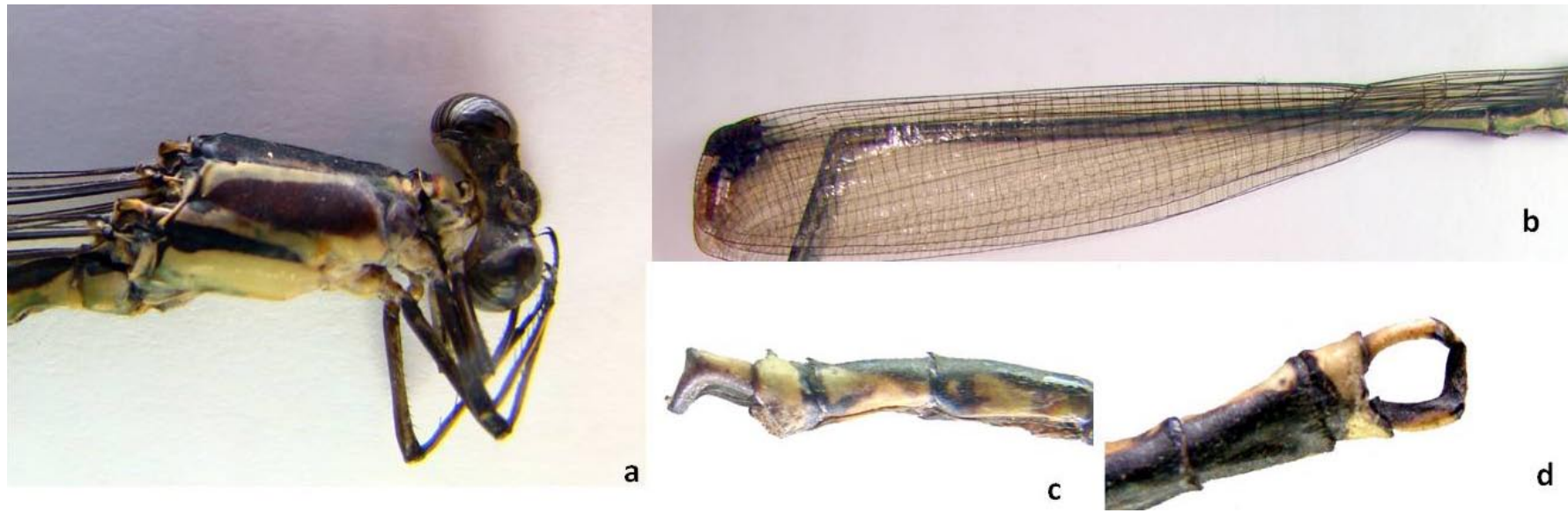

Figure 1. Mecistogaster amalia: (a) Overview of head and sinthorax; (b) Caudal appendices: dorsal view; (c) Caudal appendices: lateral view; (d) Wings.

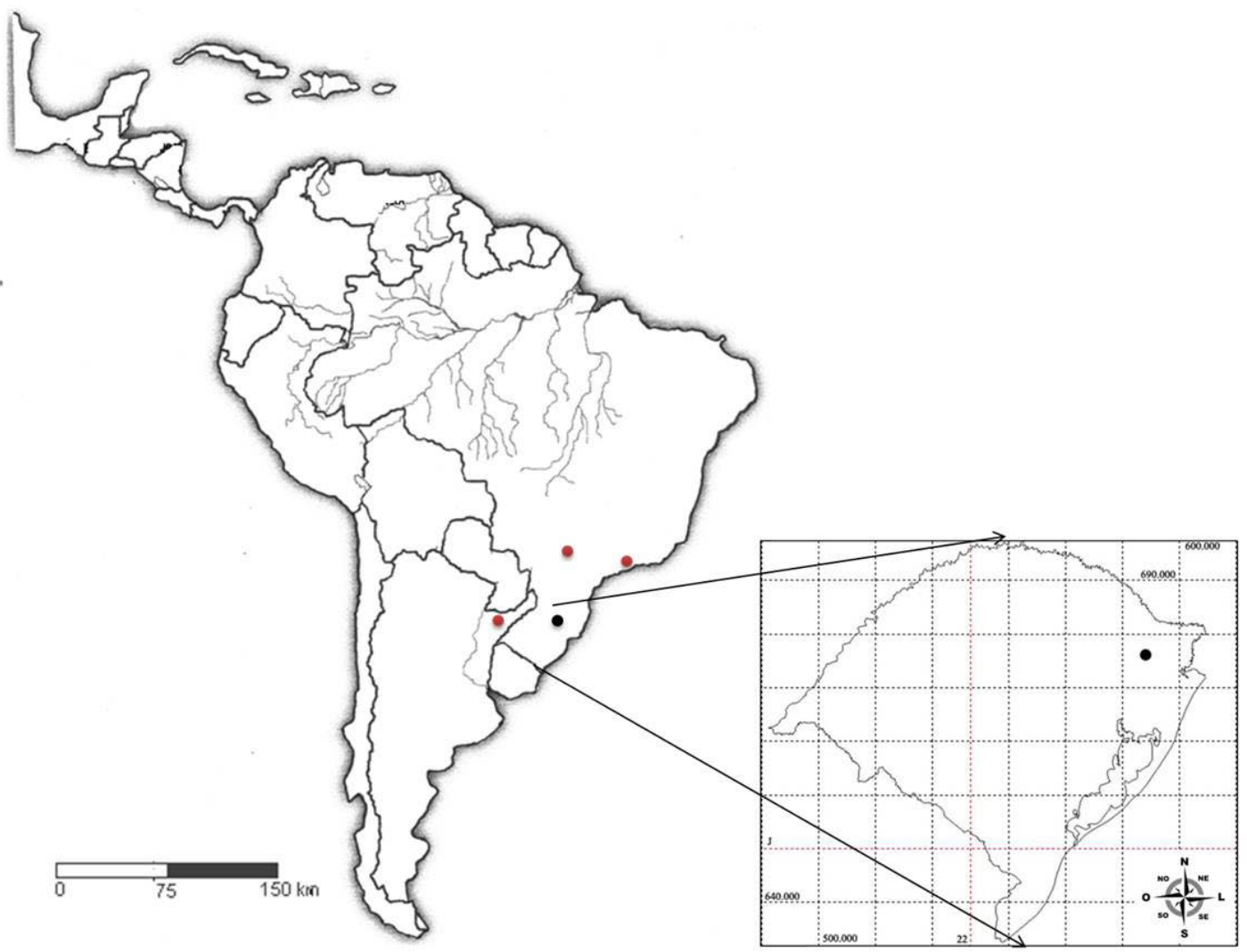

Figure 2. Previous known distribution (red points) of Mecistogaster amalia and the current record (black points).

\section{ACKNOWLEDGEMENTS}

This research was supported by funds from Palanquinho Small Hydropower Plant (SHP). Thanks to Emily Jean Toriani Moura for help with the text.

\section{REFERENCES}

Bisby, F.A., Y.R. Roskov, T.M. Orrell, D. Nicolson, L.E. Paglinawan, N. Bailly, P.M. Kirk, T. Bourgoin \& G. Baillargeon, 2010. Species 2000 \& ITIS Catalogue of Life: 2010 Annual Checklist. Available at: http://www.catalogueoflife.org/ annual-checklist/2010. Species 2000: Reading, UK. Acessed on 31 August 2010.

Heckman, C.W., 2006. Encyclopedia of South American Aquatic Insects: Odonata - Anisoptera. Illustrated Keys to Known Families, Genera, and Species in South America. Dordrecht:

\section{Como citar este artigo:}

Dalzochio, M.S., Y. Urakami \& I.F. Machado 2011. Mecistogaster amalia (Burmeister) Odonata: Pseudostigmatidae: First Record from Rio Grande do Sul State, Brazil. EntomoBrasilis, 4(2): 78-79. www.periodico.ebras.bio.br/ojs
Springer. viii $+725 \mathrm{p}$.

Lencioni, F.A.A., 2005. Damselflies of Brazil. An illustrated guide. 1 - Non-Coenagrionidae families. São Paulo: All Print Editora. iv $+324 \mathrm{p}$.

Muzón, J., S. Weigel Muñoz \& R.E. Campos, 2010 The larva of Mecistogaster amalia (Odonata: Pseudostigmatidae). International Journal of Odonatology, 13: 137-144.

von Ellenrieder, N. \& D. Paulson, 2006. Mecistogaster amalia. In: IUCN 2010. IUCN Red List of Threatened Species. Version 2010.2. Available at: <www.iucnredlist.org $>$. Acessed on 31 August 2010.

Recebido em: 26/11/2010

Aceito em: 20/07/2011

$* * * * * * * * * * * * *$

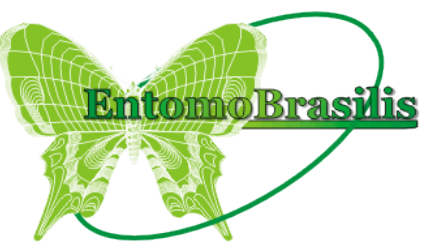

